\title{
THE 1930 SANTA MONICA AND THE 1979 MALIBU, CALIFORNIA, EARTHQUAKES
}

\author{
By Egill Hauksson and Geoffrey V. Saldivar
}

\begin{abstract}
The Malibu earthquake $\left(M_{L}=5.0\right)$ that occurred 1 January 1979 in Santa Monica Bay was located at $33^{\circ} 56.9^{\prime} \mathrm{N}$ and $118^{\circ} 41.3^{\prime} \mathrm{W}$ and at a depth of $10 \mathrm{~km}$. The focal mechanism of the main shock as determined from first motions recorded by short-period, high-gain seismic stations in southern California shows reverse faulting with one plane dipping $55^{\circ}$ to $60^{\circ}$ to the north striking $275^{\circ}$ to $290^{\circ}$, and the second plane dipping $30^{\circ}$ to $38^{\circ}$ to the south and striking $100^{\circ}$ to $120^{\circ}$. More than 400 aftershocks were recorded during 1979. Focal mechanisms for 20 aftershocks of $M \geqq 3.0$ show similar reverse mechanisms as the main shock. The main shock and aftershocks $(M \geqq 2.5)$ were relocated using a local velocity model and a set of corresponding station delays. The aftershocks define a volumetric hypocentral zone, $4 \mathrm{~km} \times 6 \mathrm{~km}$, west-trending with depths ranging from 6 to 11 $\mathrm{km}$. This 1979 Malibu main shock-aftershock sequence probably occurred on the eastern end of the Anacapa-Dume fault. The Santa Monica earthquake $\left(M_{L}=5.2\right)$ that occurred 31 August 1930 was relocated using station delays calculated from the 1979 date set. The relocated 1930 epicenter is located near the western end of the Santa Monica fault. The 1979 and $\mathbf{1 9 3 0}$ main shocks can be interpreted to define a 8- to 10-km north-south sidestep between the Anacapa-Dume and Santa Monica faults. Possible segmentation of these two fault systems suggests that they are unlikely to rupture simultaneously in one large earthquake.
\end{abstract}

\section{INTRODUCTION}

Since 1930, two moderate-sized earthquakes of magnitude 5.2 and 5.0 have been reported in the Santa Monica Bay, southern California. The 1930 Santa Monica main shock-aftershock sequence that was studied by Gutenberg et al. (1932) occurred on 31 August 1930 at approximately 00:40 (UTC). The more recent 1979 Malibu main shock-aftershock sequence that took place on 1 January 1979 at 23:14 (UTC) is the primary focus of this paper. Both main shocks were felt throughout the Los Angeles basin, and minor damage such as small rock and earth slides, broken windows, and fallen store shelf items were reported (Gutenberg et al., 1932; Stover et al., 1980). No surface rupture was reported for either main shock, but both occurred offshore.

The epicenters of the 1930 and 1979 main shocks are located in Santa Monica Bay, to the west of the Los Angeles basin. Two very different styles of faulting and crustal deformation occur in Santa Monica Bay. The frontal fault system of the Transverse Ranges, which shows predominantly reverse faulting, strikes east-west along the northern edge of Santa Monica Bay (Figure 1). In the southern part of Santa Monica Bay, the tectonic deformation is characterized by right-lateral strike slip faulting along north-northwest-trending faults with some cases of reverse faulting (Ziony and Yerkes, 1985). Since the Bay is covered by sediments that are being transported out to the Santa Monica basin, the intersection of the westtrending and the north-northwest-trending faults in Santa Monica Bay remains poorly understood (Clarke et al., 1985).

The main purpose of this paper is to evaluate if the 1930 and 1979 main shockaftershock sequences are associated with the west-trending reverse faults or the 


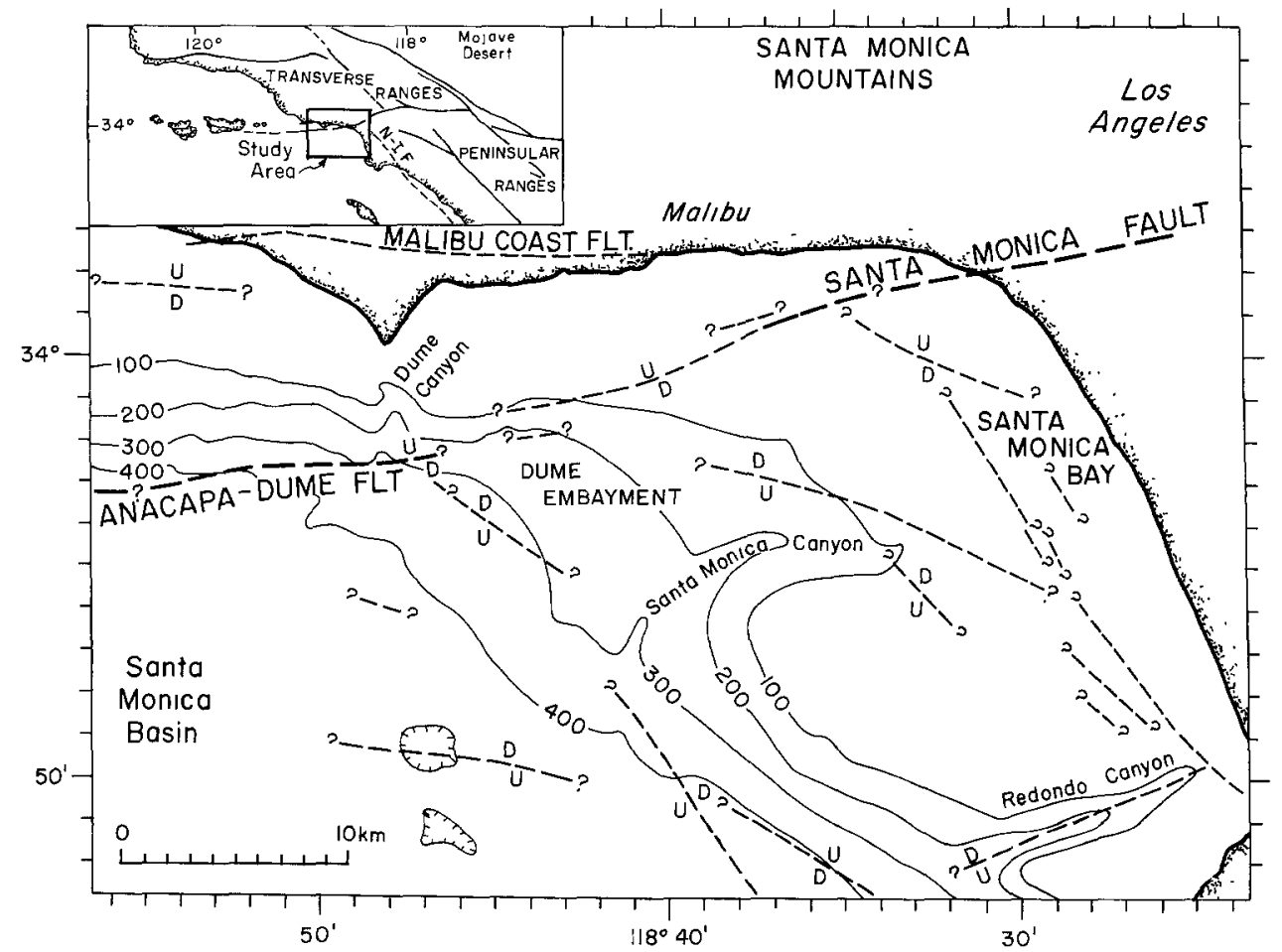

FIG. 1. (Upper left) The study area that is located near the eastern edge of the intersection of the Transverse Ranges and the Peninsular Ranges. Below is a detailed map of the study area, Santa Monica Bay, southern California. Location of faults is from Ziony et al. (1974). Faults labeled with question marks are derived from interpretation of shallow seismic profiling. The letters $D$ and $U$ indicate downthrow or upthrow side, respectively.

north-northwest-trending strike-slip faults in Santa Monica Bay. If these sequences are associated with the southern margin of the western Transverse Ranges, similar focal mechanisms of reverse faulting and aftershock distribution would be expected as were observed for the 1971 San Fernando earthquake $\left(M_{L}=6.4\right)$ and the 1973 Point Magu earthquake $\left(M_{L}=6.0\right)$ (e.g., Whitcomb et al., 1973; Stierman and Ellsworth, 1976). Alternatively, if these sequences are associated with the northnorthwest-trending strike-slip faults, strike-slip focal mechanisms and an almost planar, north-northwest-trending vertical distribution of aftershocks would be expected as was reported by Corbett (1984) for the 1981 Santa Barbara Island $\left(M_{L}=\right.$ 5.3) earthquake.

Detailed analyses of the 1930 and 1979 main shock-aftershock sequences may contribute to the understanding of how the transition of strike-slip faulting on north-northwest-striking faults to reverse faulting on west-trending faults is accommodated in Santa Monica Bay. Moreover, resolution of the southernmost margin of the frontal fault system of the Transverse Ranges would facilitate evaluations of seismic hazards in the Los Angeles basin. The occurrence of the 1971 San Fernando $\left(M_{L}=6.4\right)$ earthquake demonstrated that 15 - to 25 -km-long fault segments within the frontal fault system (e.g., Santa Monica fault, Hollywood-Raymond Hills fault) are capable of generating damaging earthquakes (Whitcomb et al., 1973). Furthermore, understanding the fault segmentation of the Anacapa-Dume and Santa Monica fault systems is important for determining the magnitude of the maximum credible earthquake as well as evaluating likely earthquake magnitude for noncritical 
facilities (Ziony and Yerkes, 1985).

The detailed analysis of the $1979 \mathrm{Malibu}$ sequence consisted of relocating the main shock and 53 aftershocks $(M \geqq 2.5$ ), using a local velocity model and corresponding station delays. Single-event, lower hemisphere focal mechanisms are determined for the main shock and aftershocks of magnitude greater than 3.0. The 1930 and 1979 California Institute of Technology (CIT) Wood-Anderson photographic records of the Santa Monica and the Malibu main shocks are examined, and the 1930 main shock is relocated using station delays calculated from the 1979 arrival times.

\section{EARTHQUAKE DATA}

Preliminary locations of seismicity reported during July-December 1978 and 1979 in Santa Monica Bay by the CIT/U.S. Geological Survey (USGS) southern California seismic network are shown in Figure 2. Since most of the aftershocks are located near the main shock, a study zone from $33^{\circ} 50^{\prime} \mathrm{N}$ to $34^{\circ} 7^{\prime} \mathrm{N}$ and from $118^{\circ} 49^{\prime} \mathrm{W}$ to $118^{\circ} 36^{\prime} \mathrm{W}$ (which included all of the aftershock of $M \geqq 2.5$ ) was chosen (Figure 2). Using the CIT catalog magnitudes, the main shock $\left(M_{L}=5.0\right)$, an $M_{L}=4.2$ aftershock from October 1979, 19 aftershocks $3.0 \leqq M_{L}<4.0$, and 33 aftershocks $2.5 \leqq M_{L}<3.0$ were selected for relocation.

Initial efforts to work with arrival times of $P$ and $S$ waves made from the CIT/ USGS network indicated the need to review phase arrival times and first motions for possible inconsistencies. To maximize the available number of first motions and to include all $P$-wave arrivals as well as crucial $S$-wave arrivals, the CIT/USGS digital seismograms of the 1979 Malibu main shock-aftershock sequence were reviewed.

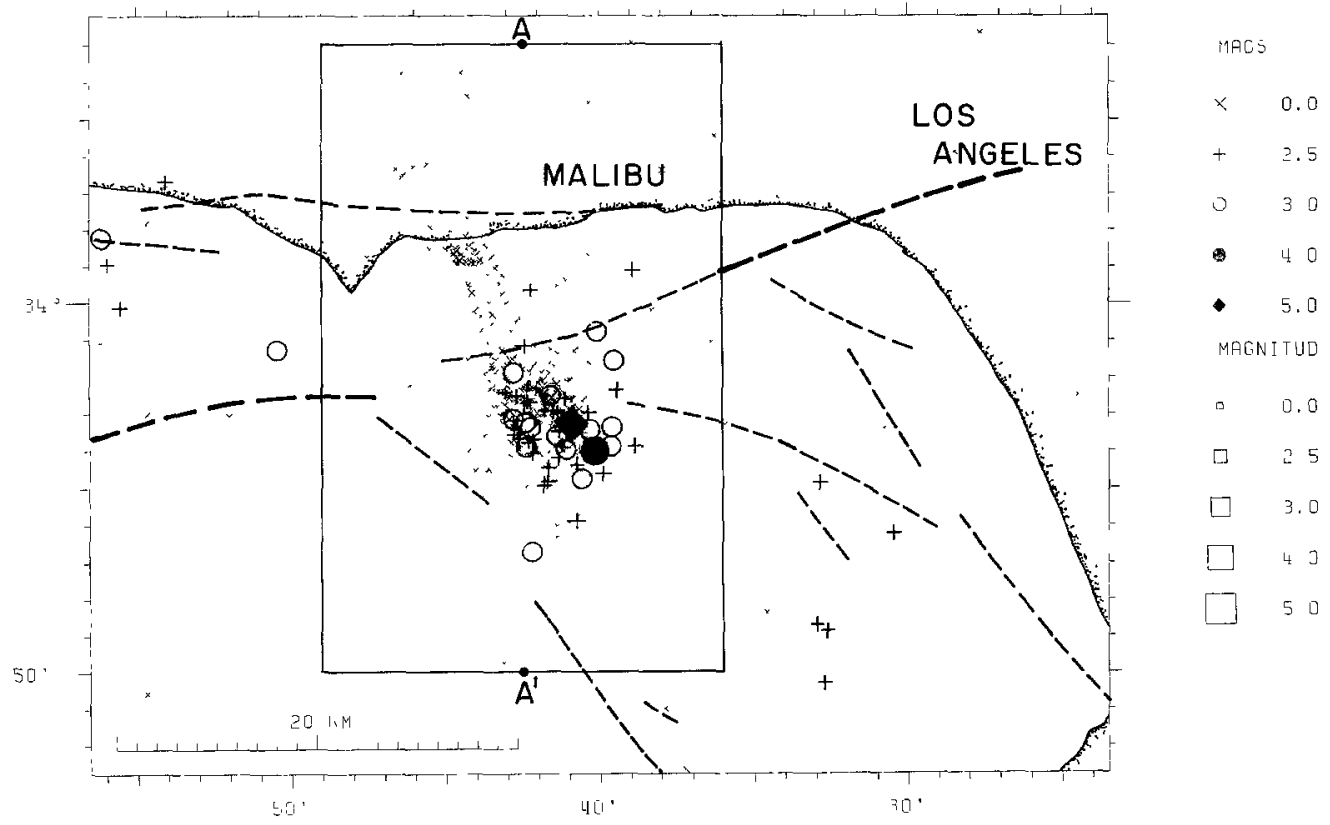

FIG. 2. Seismicity reported from July 1978 through December 1979 in Santa Monica Bay by the CIT/ USGS network. 'The rectangle labeled A-A' delineates aftershocks selected for relocation and determination of focal mechanisms. The main shock $\left(M_{L}=5.0\right)$ shows as a filled diamond, and the largest aftershock $\left(M_{L}=4.2\right)$ is shown as a filled circle. 
The University of Southern California (USC) Los Angeles basin and Santa Barbara Channel networks also recorded the 1979 Malibu sequence. The USC Los Angeles basin arrival time data were combined with the CIT/USGS data to improve station coverage from northeast to southeast. Since the USC Los Angeles basin stations are clustered at similar azimuths and often have large positive residuals, these were assigned less importance in calculating the hypocenters. The USC Santa Barbara arrival time data were not included, since for some of the events, no arrival times were available. However, first motion data, when available from the USC Santa Barbara Channel stations, were included in the focal mechanisms.

A velocity model derived for the northeastern Continental Borderlands (Table 1) by Corbett (1984) was used for relocating the sequence. This velocity model is based on arrival time data from a large quarry blast that was detonated on southeast Santa Catalina Island in November 1981 (Given and Koesterer, 1983). The velocity model applies to the crustal structure of the coastal areas around the epicentral region but may not apply to the crustal structure structure inland. To reduce the influence of lateral variations in crustal structure, the $P$ residuals of the main shock are used as station delays to relocate the aftershock sequence. Since the observed travel times for the main shock do not show systematic variations with azimuth (Figure 3), one velocity model and a set of station corrections should be sufficient to account for lateral variations in velocity structure. The HYPOINVERSE location program (Klein, 1985) was used with a cosine distance taper (applied after 4 iterations) from 75 to $150 \mathrm{~km}$ to relocate the sequence.

Lower hemisphere focal mechanisms of single events were determined for the 21 earthquakes $\left(M_{L} \geqq 3.0\right)$. Polarities of reversed stations were corrected using information from Norris et al. (1986). The initial focal mechanism solutions were determined using a grid-searching algorithm and computer programs by Reasenberg and Oppenheimer (1985). For each earthquake, questionable first motions that are located near nodal planes on the equal area projection were checked against the digital seismograms and reduced travel-time curves (Figure 3). Reduced travel-time diagrams similar to the one shown in Figure 3 were used to identify arrivals that are calculated as refracted by the location program but are in fact direct arrivals. Final nodal planes were plotted using an interactive computer program for plotting focal mechanisms. Impulsive first motions observed at fast stations in the central Transverse Ranges often were observed to be inconsistent with the other first motions. This inconsistency was removed by assigning a faster velocity structure to these stations and hence increasing the ray take-off angle. The faster velocity structure was obtained by removing the top layer of the Corbett (1984) velocity model in Table 1. This deviation may result from the longer path (both downgoing and upgoing rays) of rays from the Santa Catalina blast through the sediments of the Santa Monica and San Pedro basins. Rays from the Malibu sequence would

TABLE 1

Corbett's (1984) Velocity Model Used for Relocating the Santa Monica Bay Earthquakes

\begin{tabular}{cc}
$\begin{array}{c}P \text {-Wave } \\
\text { Velocity } \\
(\mathrm{km} / \mathrm{sec})\end{array}$ & $\begin{array}{c}\text { Depth to } \\
\text { Top of Layer } \\
(\mathrm{km})\end{array}$ \\
\hline 5.2 & 0 \\
6.3 & 5.5 \\
7.8 & 22.0 \\
\hline
\end{tabular}




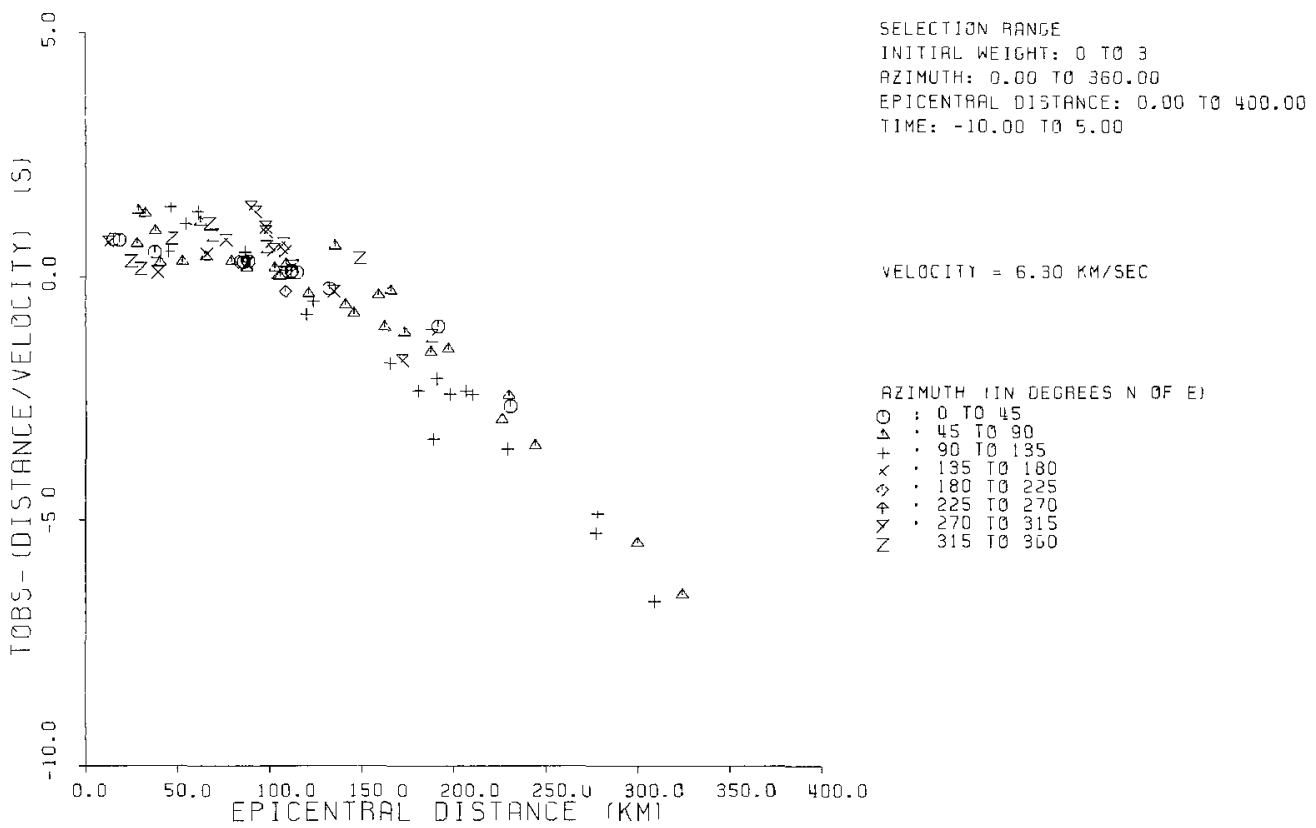

FIG. 3. A reduced travel-time curve of observed travel times for the 1979 main shock. The reduction velocity is $6.3 \mathrm{~km} / \mathrm{sec}$. The symbol type depends on azimuth.

TABLE 2

$P$-Wave Arrival Times (from Cit Phase Cards) for the 1930 Santa Monica and 1979 Malibu Main Shocks at CIT Stations that Recorded Both Events

\begin{tabular}{|c|c|c|c|c|c|}
\hline \multirow{2}{*}{ Station } & \multirow{2}{*}{$\begin{array}{l}\text { Station } \\
\text { Delay } \\
\text { (sec) }\end{array}$} & \multicolumn{2}{|c|}{$\begin{array}{l}31 \text { August } 1930 \\
\text { 01h:40m (UTC) }\end{array}$} & \multicolumn{2}{|c|}{$\begin{array}{l}1 \text { January } 1979 \\
23 \mathrm{~h} .14 \mathrm{~m} \text { (UTC) }\end{array}$} \\
\hline & & $\begin{array}{c}P \\
(\mathrm{sec})\end{array}$ & $\begin{array}{c}S \\
\text { (sec) }\end{array}$ & $\begin{array}{c}P \\
(\mathrm{sec})\end{array}$ & $\begin{array}{c}S \\
(\mathrm{sec})\end{array}$ \\
\hline Pasadena (PAS) & -0.18 & 45.4 & 50.0 & 47.5 & 54.3 \\
\hline Riverside (RVR) & -0.30 & 57.3 & 70.1 & 58.0 & 72.6 \\
\hline Santa Barbara (SBC) & 0.02 & 56.4 & 69.0 & 56.9 & \\
\hline La Jolla (LJC) & 1.25 & 66.8 & 88.6 & $64.4^{*}$ & \\
\hline Haiwee (HAI) & 0.88 & 74.4 & 99.4 & $75.1 \dagger$ & \\
\hline
\end{tabular}

* Synthetic $P$-wave arrival time derived from a $P$-wave arrival time at $\mathrm{CPE}$ with a distance correction.

$\dagger$ Synthetic $P$-wave arrival time derived from a $P$-wave arrival time at CLC with a distance correction.

only travel from depth up to stations in the Santa Monica Mountains and not pass through basin sediments.

The 1930 Santa Monica main shock was recorded by five stations with clock corrections [Pasadena (PAS), Riverside (RVR), Santa Barbara (SBC), La Jolla (LJC), and Haiwee (HAI)] in southern California. The arrival times from the Caltech phase cards which are used to generate the Caltech earthquake catalog, were compared with the original seismograms and were found to be consistent. A notebook of C. F. Richter in the Caltech archives also lists the same arrival times as the phase cards (Table 2). Gutenberg et al. (1932), however, published slightly different arrival times that showed earlier arrivals at all stations. The largest discrepancies are early arrivals at PAS and LJC where the time difference is 0.6 
and $1.6 \mathrm{sec}$, respectively. The source of these modified arrival times is not known. Since 3 of 4 data sources show the same arrival times, these are the data used in this study. The Corbett velocity model (Table 1) was also used to relocate the 1930 main shock. A set of station delays was derived to compensate for lateral variations in the velocity structure. For the stations PAS, RVR, and SBC, the corresponding residuals of the 1979 main shock were used. Since the stations LJC and HAI were no longer in operation in 1979, we used delays derived for residuals of nearby stations (CPE and BAR were used for LJC, and CLC was used for HAI).

The 54 earthquakes in 1979 showed an unusual residual pattern at both CPE and BAR. Earthquakes of magnitude greater than 3.0 had a -0.9 sec average residual while events of magnitude less then 3.0 had a $1.25 \mathrm{sec}$ average residual. This indicated that the larger events were preceded by a low-amplitude $P_{n}$ phase of high velocity. Since the station LJC was operated at a low gain compared to the present high-gain, short-period stations at CPE and BAR, a station delay of $1.25 \mathrm{sec}$ was selected for LJC. The station CLC had in most cases a residual of 0.7 to $1.0 \mathrm{sec}$, and an average value of $0.88 \mathrm{sec}$ was chosen as a station delay for HAI.

The phase card arrival times for all of the stations except PAS yielded a consistent solution when using these delays and the Corbett velocity model. The PAS $P$-wave residual was $-1.9 \mathrm{sec}$, while the other stations had $P$-wave residuals ranging from -0.31 to $0.22 \mathrm{sec}$. Hence, the PAS station is not used to calculate the epicenter. If PAS were given full weight, the high residual shifts from PAS to the station RVR and the epicenter moves $18 \mathrm{~km}$ to the east-northeast. Gutenberg et al. (1932), who located the 1930 main shock, also did not use PAS to determine the epicenter. Unfortunately, they did not explain why PAS was not included. A comparison of the 1930 and 1979 main shock arrival times in Table 2 (except for station PAS) shows that the 1930 event has to be located to the northeast of the 1979 epicenter. To facilitate comparison of the arrival times of the 1930 and 1979 main shocks, synthetic $P$-wave arrival times are shown in Table 2 for the 1979 main shock at stations LJC and HAI, since these stations were not in operation in 1979. The synthetic $P$-wave arrival times were derived by using the observed arrival time at a nearby station and adding a distance correction, assuming a $P$-wave velocity of 7.8 $\mathrm{km} / \mathrm{sec}$. Since data from stations located close to the epicenter were not available, the depth was fixed at $15 \mathrm{~km}$.

A quantitative comparison of the Wood-Anderson records of the 1979 and 1930 main shocks was not possible, since the 1979 records are obscured by a large aftershock.

\section{RESULTS}

Earthquake locations. The Malibu earthquake $\left(M_{L}=5.0\right)$ that occurred on 1 January 1979 at 23:14:38.9 (UTC) was followed by numerous aftershocks located near Dume Embayment in Santa Monica Bay (Figures 1 and 2).

Figure 4 shows a histogram of the number of earthquakes observed from 1 July 1978 to the end of 1979 in the study area (Figure 2). The $M_{L}=5.0$ was not preceded by foreshock activity, and the rate of aftershock activity was unusually high. The largest aftershock $\left(M_{L}=4.2\right)$ occurred 9 months after the main shock in October 1979 and was followed by its own aftershock sequence.

The epicenter of the main shock is located $10 \mathrm{~km}$ due south of the Malibu coast, in the Dume Embayment (Figure 5 and Table 3). The hypocenter of the main shock is at a depth of $10 \mathrm{~km}$, near the bottom of the aftershock zone. 


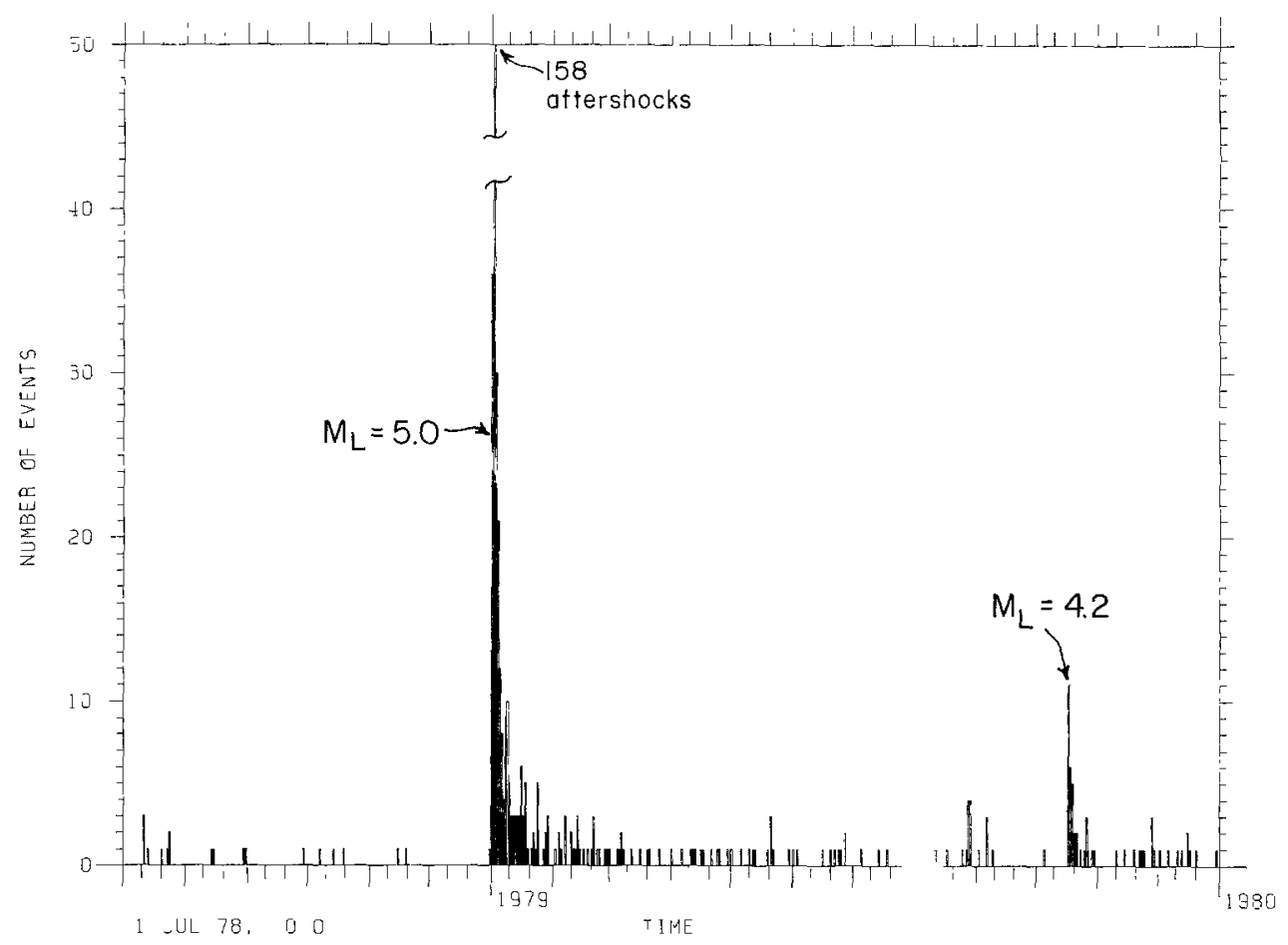

FIG. 4. A histogram of the number of aftershocks per day reported in the CIT/USGS catalog from July 1978 through December 1979, within the rectangle shown in Figure 2.

To determine accurately the spatial distribution of the hypocenters of this main shock-aftershock sequence, the sequence was relocated using a local velocity model and the $P$ residuals of the main shock as station delays. The relocated $M \geqq 2.5$ aftershocks that are listed in Table 4 define a tightly clustered zone around the main shock (approximately $4 \mathrm{~km}$ wide and $6 \mathrm{~km}$ long) between 6 and $11 \mathrm{~km}$ depth (Figure 5). The relative uncertainty in epicentral location is approximately $1 \mathrm{~km}$ while the relative uncertainty in depth is $\pm 2 \mathrm{~km}$. Since the closest stations (PTD, SAD, TPR, and KYP) are located 10 to $15 \mathrm{~km}$ north of the epicenters and had negative residuals, it is possible that the calculated epicenters could be biased toward the north. The stations located on the Palos Verdes Peninsula and Santa Catalina Island and $S$-wave arrival times, however, help minimize the possible bias in the calculated epicenters. The aftershocks define an epicentral zone of $4 \mathrm{~km} \times 6$ $\mathrm{km}$. An independent analysis of $S-P$ travel times to stations located to the north and east indicates that the observed distribution is real and does not result from the lack of stations within the epicentral area. The volumetric rather than planar distribution of the aftershocks, however, suggests that some slip took place on minor faults subparallel to the rupture surface of the main shock (Figure 5).

The relocated main shock and aftershock hypocenters do not show a simple spatial correspondence to the mapped faults in Santa Monica Bay. The depth sections $\mathrm{B}^{-\mathrm{B}^{\prime}}$ and $\mathrm{C}-\mathrm{C}^{\prime}$ do not reveal a simple dipping linear distribution of hypocenters and do not uniquely determine if the main shock-aftershock sequence is associated with a vertical, south-dipping or north-dipping fault, based solely on the spatial distribution of hypocenters. Nonetheless, the west-trending distribution of epicenters in Figure 5 does suggest that the 1979 Malibu sequence is associated with a west-trending fault. 

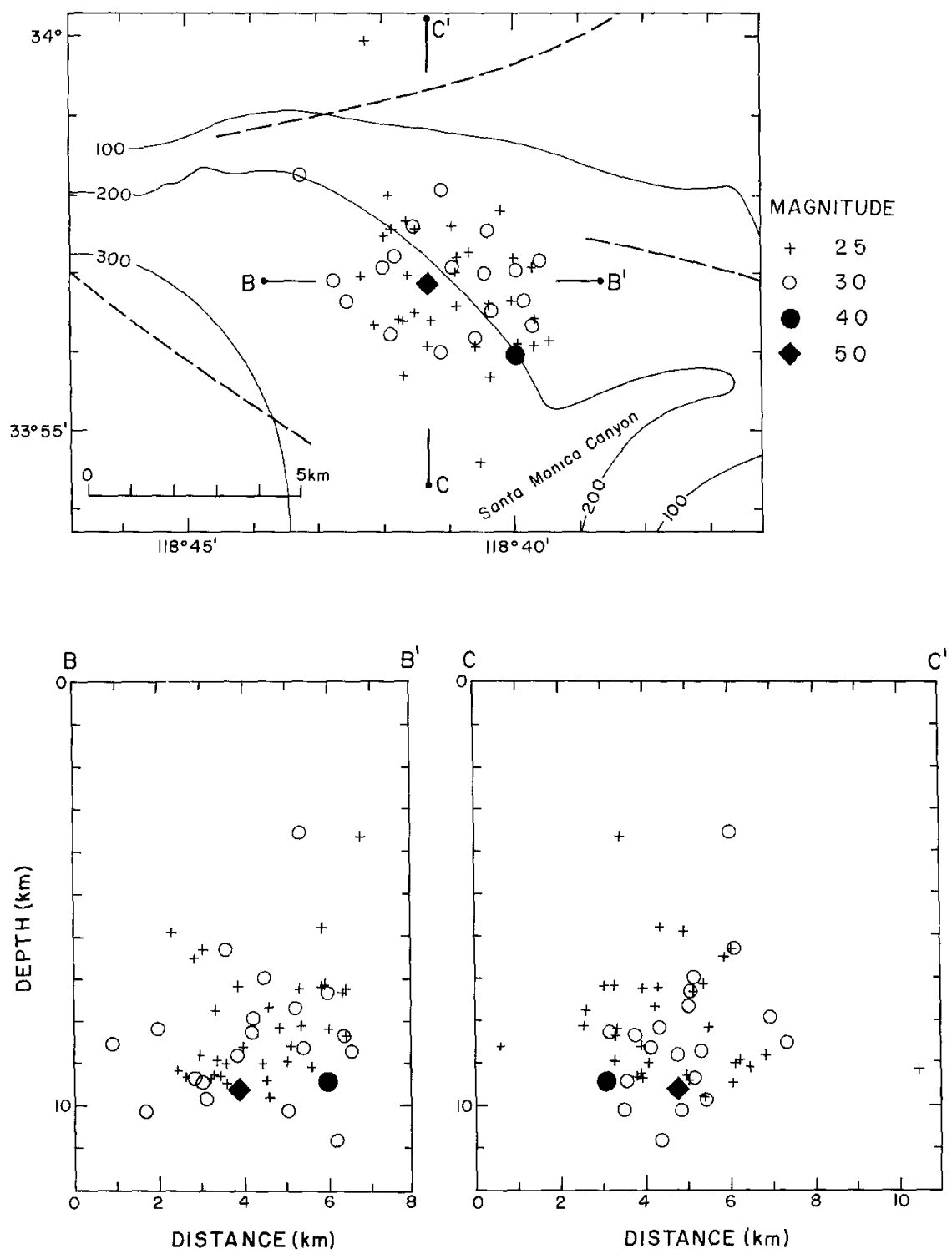

FIG. 5. The relocated main shock and aftershocks of the 1 January 1979 Malibu earthquake $(M=$ 5.0). (Top) An epicentral map and (bottom) depth sections along the lines B-B' and C-C'. The main shock $\left(M_{L}=5.0\right)$ is shown as a filled diamond; the largest aftershock $\left(M_{L}=4.2\right)$ is shown as a filled circle. Earthquakes of $M \geqq 3.0$ are shown as open circles, and $2.5 \leqq M<3.0$ are shown as plus symbols.

TABLE 3

Hypocentral Parameters of the 1930 and 1979 Main Shocks

\begin{tabular}{ccccc}
\hline Earthquake & Date & $\begin{array}{c}\text { Latitude } \\
\left({ }^{\circ} \mathrm{N}\right)\end{array}$ & $\begin{array}{c}\text { Longtude } \\
\left({ }^{\circ} \mathrm{W}\right)\end{array}$ & $\begin{array}{c}\text { Depth } \\
(\mathrm{km})\end{array}$ \\
\hline Santa Monica & 31 August 1930 & $34^{\circ} 1.8^{\prime}$ & $118^{\circ} 38.6^{\prime}$ & 15 (fixed depth) \\
Malibu & 1 January 1979 & $33^{\circ} 56.9^{\prime}$ & $118^{\circ} 41.3^{\prime}$ & $9.6 \pm 2$ \\
\hline
\end{tabular}


TABLE 4

Hypocentral Parameters and Focal Mechanisms of the 1979 Malibu Main ShockAFTERSHOCK SEQUENCE

\begin{tabular}{|c|c|c|c|c|c|c|c|c|c|c|c|c|c|c|}
\hline \multirow[b]{2}{*}{ No ${ }^{*}$} & \multirow[b]{2}{*}{$\begin{array}{c}\text { Date } \\
(\mathrm{yr} / \mathrm{mo} / \text { day })\end{array}$} & \multirow[b]{2}{*}{$\begin{array}{l}\text { Trme } \\
\text { (UTC) }\end{array}$} & \multicolumn{4}{|c|}{ Location } & \multirow{2}{*}{$\begin{array}{c}\text { Depth } \\
(\mathrm{km})\end{array}$} & \multirow[b]{2}{*}{ Magnitude } & \multirow{2}{*}{$\begin{array}{l}\text { RMS } \\
(\mathrm{sec})\end{array}$} & \multirow{2}{*}{$\begin{array}{l}\text { ERH } \\
(\mathrm{km})\end{array}$} & \multirow{2}{*}{$\begin{array}{l}\mathrm{ERZ} \\
(\mathrm{km})\end{array}$} & \multicolumn{3}{|c|}{ Focal Mechanısm $\dagger$} \\
\hline & & & \multicolumn{2}{|c|}{$\begin{array}{c}\text { Latitude } \\
\left({ }^{\circ} \mathrm{N}\right)\end{array}$} & \multicolumn{2}{|c|}{$\begin{array}{c}\text { Longitude } \\
\left({ }^{\circ} \mathrm{W}\right)\end{array}$} & & & & & & Dir & Dip & Rake \\
\hline 1 & $79 / 01 / 01$ & $23: 14$ & $33^{\circ}$ & $56.9^{\prime}$ & $118^{\circ}$ & $41.3^{\prime}$ & 9.6 & 5.0 & 0.00 & 0.1 & 0.1 & 10 & 60 & 85 \\
\hline 2 & $79 / 01 / 01$ & $23: 19$ & 33 & 58.2 & 118 & 43.2 & 8.5 & 3.2 & 0.24 & 0.3 & 0.7 & 10 & 45 & 83 \\
\hline 3 & $79 / 01 / 01$ & $23: 21$ & 33 & 57.6 & 118 & 41.5 & 6.3 & 3.1 & 0.26 & 0.4 & 1.4 & 15 & 40 & 102 \\
\hline 4 & $79 / 01 / 01$ & $23: 22$ & 33 & 56.2 & 118 & 41.9 & 9.4 & 3.4 & 0.18 & 0.3 & 0.4 & 350 & 65 & 63 \\
\hline \multirow[t]{2}{*}{5} & $79 / 01 / 01$ & $23: 24$ & 33 & 57.0 & 118 & 39.9 & 7.3 & 3.0 & 0.29 & 0.4 & 0.7 & 355 & 52 & 77 \\
\hline & $79 / 01 / 01$ & $23: 25$ & 33 & 54.6 & 118 & 40.5 & 8.6 & 2.6 & 0.17 & 0.3 & 0.6 & & & \\
\hline 6 & $79 / 01 / 01$ & $23: 26$ & 33 & 57.5 & 118 & 40.4 & 3.5 & 3.0 & 0.33 & 0.5 & 0.6 & 10 & 62 & 61 \\
\hline 7 & $79 / 01 / 01$ & $23: 29$ & 33 & 57.0 & 118 & 40.4 & 7.7 & 3.9 & 0.36 & 0.4 & 1.0 & 360 & 50 & 57 \\
\hline \multirow[t]{3}{*}{8} & $79 / 01 / 01$ & $23: 32$ & 33 & 57.1 & 118 & 40.9 & 7.0 & 3.0 & 0.29 & 0.5 & 1.0 & 20 & 72 & 82 \\
\hline & $79 / 01 / 01$ & $23: 43$ & 33 & 56.5 & 118 & 41.5 & 9.0 & 2.5 & 0.20 & 0.3 & 0.5 & & & \\
\hline & $79 / 01 / 01$ & $23: 43$ & 33 & 56.6 & 118 & 40.4 & 7.2 & 2.6 & 0.18 & 0.3 & 0.7 & & & \\
\hline 9 & $79 / 01 / 01$ & $23: 49$ & 33 & 56.2 & 118 & 40.6 & 10.1 & 3.7 & 0.25 & 0.5 & 0.5 & 10 & 60 & 71 \\
\hline 10 & $79 / 01 / 02$ & $0: 03$ & 33 & 56.9 & 118 & 41.3 & 8.8 & 3.0 & 0.27 & 0.5 & 0.9 & 20 & 56 & 68 \\
\hline & $79 / 01 / 02$ & $2: 54$ & 33 & 57.6 & 118 & 41.6 & 8.9 & 2.9 & 0.18 & 0.3 & 0.5 & & & \\
\hline & $79 / 01 / 02$ & $3: 01$ & 33 & 57.0 & 118 & 41.6 & 9.3 & 2.6 & 0.19 & 0.3 & 0.5 & & & \\
\hline & $79 / 01 / 02$ & $3: 33$ & 33 & 56.4 & 118 & 41.7 & 9.3 & 2.7 & 0.11 & 0.2 & 0.3 & & & \\
\hline & $79 / 01 / 02$ & $6: 21$ & 33 & 57.6 & 118 & 41.5 & 9.5 & 2.7 & 0.12 & 0.2 & 0.3 & & & \\
\hline 11 & $79 / 01 / 02$ & $7: 15$ & 33 & 57.2 & 118 & 41.8 & 9.9 & 3.0 & 0.12 & 0.2 & 0.3 & 25 & 48 & 73 \\
\hline 12 & $79 / 01 / 02$ & $7: 41$ & 33 & 56.6 & 118 & 42.5 & 8.2 & 3.7 & 0.19 & 0.3 & 0.6 & 10 & 51 & 80 \\
\hline & $79 / 01 / 02$ & $7: 42$ & 33 & 56.9 & 118 & 42.3 & 5.9 & 2.7 & 0.25 & 0.4 & 1.6 & & & \\
\hline & $79 / 01 / 02$ & $14: 11$ & 33 & 56.4 & 118 & 41.2 & 8.6 & 2.5 & 0.17 & 0.3 & 0.5 & & & \\
\hline & $79 / 01 / 02$ & $15: 47$ & 33 & 56.1 & 118 & 39.9 & 8.2 & 2.7 & 0.13 & 0.2 & 0.4 & & & \\
\hline & $79 / 01 / 02$ & $15: 50$ & 33 & 57.2 & 118 & 40.9 & 9.8 & 2.9 & 0.27 & 0.5 & 0.7 & & & \\
\hline 13 & $79 / 01 / 02$ & $18: 16$ & 33 & 56.0 & 118 & 41.1 & 8.3 & 3.4 & 0.16 & 0.3 & 0.5 & 10 & 50 & 90 \\
\hline & $79 / 01 / 02$ & $22: 29$ & 33 & 56.1 & 118 & 40.6 & 9.0 & 2.5 & 0.24 & 0.4 & 0.9 & & & \\
\hline & $79 / 01 / 02$ & $22: 43$ & 33 & 57.3 & 118 & 40.7 & 8.2 & 2.6 & 0.16 & 0.3 & 0.6 & & & \\
\hline & $79 / 01 / 03$ & $0: 20$ & 33 & 56.4 & 118 & 39.7 & 7.3 & 2.8 & 0.24 & 0.3 & 0.9 & & & \\
\hline & $79 / 01 / 03$ & $1: 53$ & 33 & 56.3 & 118 & 42.1 & 9.3 & 2.7 & 0.14 & 0.2 & 0.4 & & & \\
\hline & $79 / 01 / 03$ & $3: 05$ & 33 & 55.7 & 118 & 41.7 & 7.8 & 2.5 & 0.18 & 0.3 & 0.7 & & & \\
\hline & $79 / 01 / 03$ & $4: 28$ & 33 & 56.6 & 118 & 40.9 & 7.7 & 2.6 & 0.23 & 0.4 & 0.8 & & & \\
\hline & $79 / 01 / 03$ & $4: 57$ & 33 & 59.9 & 118 & 42.3 & 9.2 & 2.9 & 0.16 & 0.3 & 0.4 & & & \\
\hline 14 & $79 / 01 / 03$ & $16: 54$ & 33 & 58.0 & 118 & 41.1 & 7.9 & 3.0 & 0.16 & 0.2 & 0.5 & 360 & 51 & 80 \\
\hline 15 & $79 / 01 / 04$ & $1: 02$ & 33 & 56.5 & 118 & 40.3 & 8.7 & 3.0 & 0.15 & 0.2 & 0.5 & 355 & 62 & 61 \\
\hline & $79 / 01 / 05$ & $1: 31$ & 33 & 56.1 & 118 & 39.7 & 8.4 & 2.6 & 0.16 & 0.3 & 0.5 & & & \\
\hline & $79 / 01 / 06$ & $19: 53$ & 33 & 56.4 & 118 & 41.7 & 9.4 & 2.5 & 0.14 & 0.3 & 0.4 & & & \\
\hline & $79 / 01 / 06$ & $22: 12$ & 33 & 57.8 & 118 & 40.2 & 9.1 & 2.6 & 0.19 & 0.3 & 0.4 & & & \\
\hline & $79 / 01 / 08$ & $3: 34$ & 33 & 57.0 & 118 & 40.9 & 9.4 & 2.7 & 0.17 & 0.3 & 0.4 & & & \\
\hline & $79 / 01 / 08$ & $14: 56$ & 33 & 55.7 & 118 & 40.4 & 8.1 & 2.8 & 0.12 & 0.2 & 0.4 & & & \\
\hline & $79 / 01 / 09$ & $16: 55$ & 33 & 56.1 & 118 & 41.3 & 7.2 & 2.6 & 0.17 & 0.3 & 0.8 & & & \\
\hline & $79 / 01 / 13$ & $11: 07$ & 33 & 57.2 & 118 & 40.0 & 7.2 & 2.8 & 0.16 & 0.2 & 0.6 & & & \\
\hline 16 & $79 / 01 / 15$ & $12: 41$ & 33 & 57.1 & 118 & 42.0 & 9.3 & 3.7 & 0.11 & 0.2 & 0.3 & 15 & 62 & 68 \\
\hline & $79 / 01 / 16$ & $0: 04$ & 33 & 57.6 & 118 & 40.9 & 9.0 & 2.9 & 0.14 & 0.2 & 0.3 & & & \\
\hline 17 & $79 / 01 / 29$ & $4: 59$ & 33 & 56.6 & 118 & 39.8 & 10.8 & 3.1 & 0.19 & 0.3 & 0.4 & 10 & 62 & 80 \\
\hline & $79 / 02 / 28$ & $17: 46$ & 33 & 57.5 & 118 & 42.0 & 6.5 & 2.5 & 0.28 & 0.5 & 1.7 & & & \\
\hline 18 & $79 / 03 / 05$ & $10: 49$ & 33 & 56.9 & 118 & 42.7 & 10.1 & 3.7 & 0.15 & 0.3 & 0.4 & 15 & 60 & 93 \\
\hline & $79 / 08 / 29$ & $9: 19$ & 33 & 58.0 & 118 & 41.9 & 8.8 & 2.7 & 0.20 & 0.3 & 0.5 & & & \\
\hline & $79 / 09 / 06$ & $14: 30$ & 33 & 57.5 & 118 & 41.9 & 6.3 & 2.5 & 0.18 & 0.2 & 0.8 & & & \\
\hline 19 & $79 / 10 / 17$ & $20: 52$ & 33 & 55.9 & 118 & 40.0 & 9.4 & 4.2 & 0.12 & 0.2 & 0.4 & 5 & 57 & 79 \\
\hline & $79 / 10 / 18$ & $1: 37$ & 33 & 56.6 & 118 & 40.0 & 5.8 & 2.6 & 0.23 & 0.3 & 1.1 & & & \\
\hline 20 & $79 / 10 / 18$ & $4: 25$ & 33 & 56.3 & 118 & 39.7 & 8.4 & 3.0 & 0.19 & 0.3 & 0.5 & 10 & 70 & 92 \\
\hline & $79 / 10 / 26$ & $6: 46$ & 33 & 56.1 & 118 & 39.4 & 3.6 & 2.5 & 0.25 & 0.2 & 0.4 & & & \\
\hline & $79 / 11 / 28$ & $10: 53$ & 33 & 57.1 & 118 & 39.7 & 7.3 & 2.7 & 0.18 & 0.3 & 0.5 & & & \\
\hline & $79 / 12 / 02$ & 18:09 & 33 & 55.9 & 118 & 40.1 & 7.2 & 2.7 & 0.19 & 0.3 & 0.6 & & & \\
\hline 21 & $79 / 12 / 16$ & $6: 00$ & 33 & 57.2 & 118 & 39.6 & 8.7 & 3.2 & 0.14 & 0.2 & 0.4 & 360 & 62 & 61 \\
\hline
\end{tabular}

* Number refers to focal mechanism in Figures 7 and 10.

+ Dir, dip direction of nodal plane in degrees; dip, dip of nodal plane in degrees; rake, rake of the focal mechanısm in degrees. 
A similar main shock-aftershock sequence occurred in Santa Monica Bay in 1930 (Gutenberg et al., 1932). The 1930 main shock that had a magnitude of 5.2 (Toppozada et al., 1978) was relocated using station delays calculated with the 1979 data set as described above. The 1930 main shock epicenter is located $10 \mathrm{~km}$ to the northeast of the 1979 main shock epicenter (Figure 6 and Table 3). The relative separation of the epicenters in the east-west direction is mostly controlled by arrival times recorded at the stations SBC and RVR (also see Table 2). The station at La Jolla (LJC) to the south and Haiwee (HAI) to the north control the relative northsouth separation. If the modified Gutenberg et al. (1932) arrival times are used, the 1930 epicenter moves 4 to $6 \mathrm{~km}$ to the northeast of the 1979 epicenter. This location is at the southern edge of the north-south error bar of the preferred epicenter, determined using the phase card data (Figure 6).

The epicenter of the relocated 1930 main shock moved 8 to $10 \mathrm{~km}$ toward the north (caused by the late arrival time at LJC) as compared to the location of the 1979 main shock (Figure 6). The relative location uncertainty of the 1930 epicenter is estimated to be $\pm 2 \mathrm{~km}$ in an east-west direction and $\pm 4 \mathrm{~km}$ in a north-south direction. These estimates are based on the available station distribution, the stability of the solution depending on the importance given to PAS as well as the error ellipsoid calculated by HYPOINVERSE. To compare the location quality of the 1930 and 1979 events, the 1979 main shock was located using a similar station distribution and phase card data of similar quality as is available for the 1930 main shock. The epicenter of the 1979 main shock shifted by less than $1 \mathrm{~km}$ to the southeast away from the epicenter determined using the modern digital data. Hence, the epicenter of the 1930 main shock is considered to be reliable.

The relocated epicenter of the 1930 main shock is located near the western end of the Santa Monica fault (Figure 6). Hence, both the 1979 and 1930 main shocks

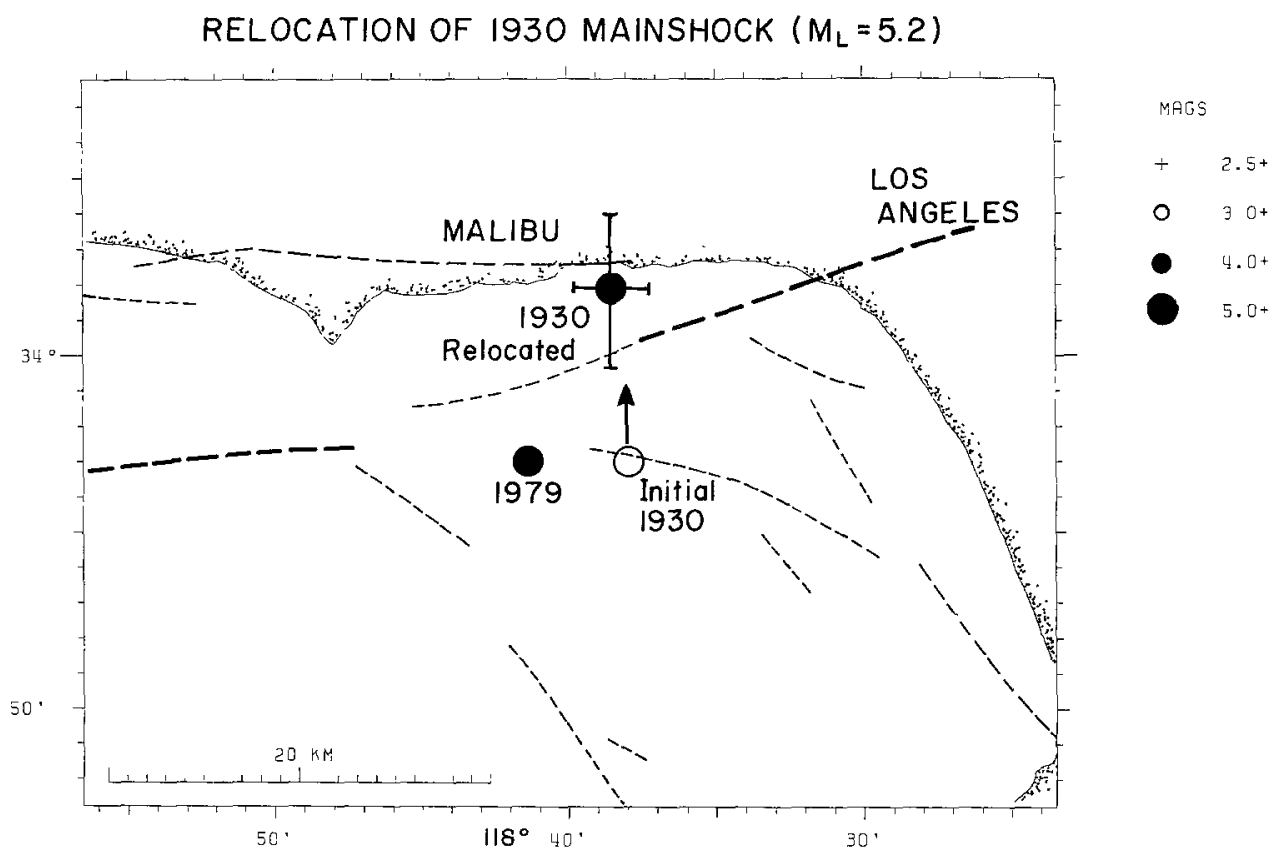

FIG. 6. Epicentral map of: (1) 1979 main shock; (2) the Gutenberg et al. (1932) initial location of the 1930 main shock; and (3) relocated epicenter of the 1930 main shock with error bars, based on the 1979 station delays. 
appear to be associated with the west-trending faults. The 1930 Santa Monica earthquake was followed by less aftershock activity than the 1979 Malibu earthquake. (Gutenberg et al. (1932) state that only 16 immediate aftershocks were recorded during the first day following the earthquake and only two or three more aftershocks were recorded in September 1930. The difference in aftershock activity (as observed in both cases at the station Pasadena) further suggests that the two main shocks occurred under different stress conditions and most likely on separate faults.

Focal mechanisms. The association of the 1979 Malibu main shock to a westtrending fault is also supported by the focal mechanisms of the main shock and 20 large aftershocks $(M \geqq 3.0)$. All of the well-constrained focal mechanisms show almost pure reverse faulting on nearly east-west striking planes (Figure 7). The northerly dipping planes of the focal mechanisms vary from $260^{\circ}$ to $295^{\circ}$ in azimuth and $40^{\circ}$ to $65^{\circ}$ in dip, while the southerly dipping planes vary from $90^{\circ}$ to $150^{\circ}$ in azimuth and $20^{\circ}$ to $51^{\circ}$ in dip. The southerly dipping planes are less well-constrained in part because there are only a few seismograph stations located to the southwest of Santa Monica Bay. The lack of constraints may also result from insufficient number of available first motions or incorrect depth determination. The more uniform orientation of the northerly dipping planes is consistent with the main shock-aftershock sequence being associated with a major north-dipping fault. This case of thrust faulting occurring on west-trending northerly dipping faults is
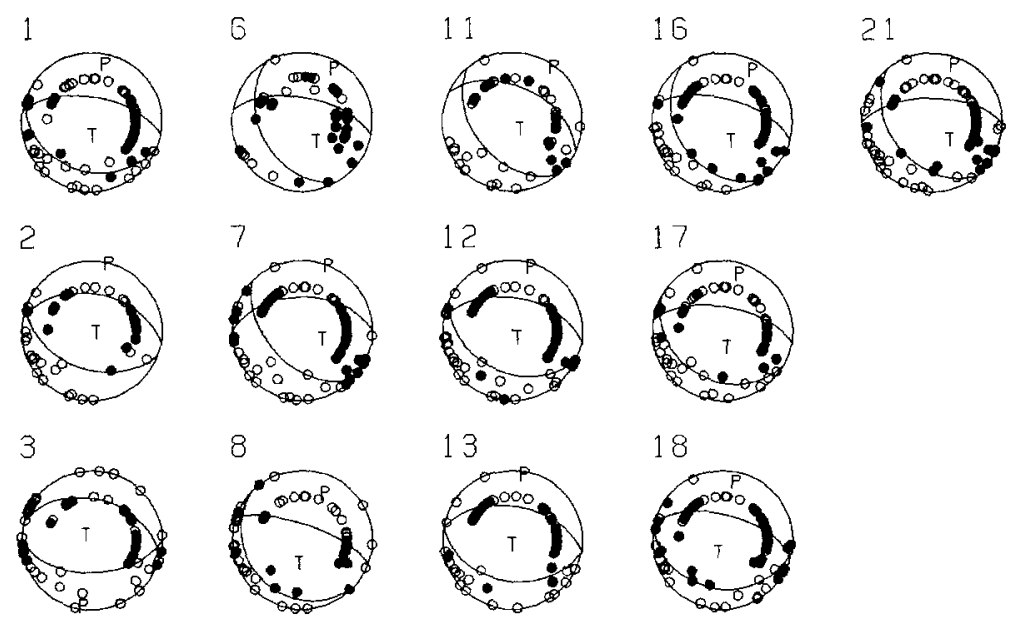

4

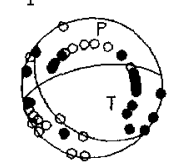

9
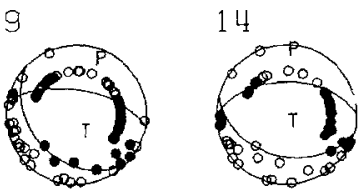

19
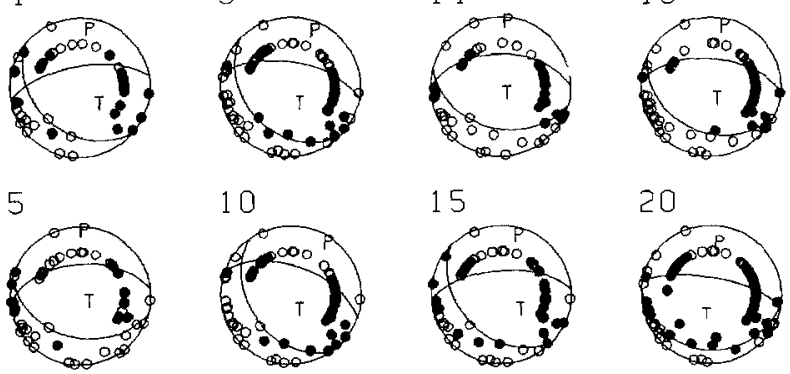

FIG. 7. Lower hemısphere (single-event) focal mechanisms of the Malibu 1979 main shock $(M=5.0)$ and 20 aftershocks of $M \geqq 3.0$. Open circles indicate dilatational first motion, and closed circles indicate compressional first motion. $P$ and $T$ axes are also shown. Numbers in the upper left-hand corner refer to Table 4. 
consistent with previous studies of moderate-sized or large earthquakes in the Transverse Ranges such as the 1971 San Fernando earthquake (Whitcomb et al., 1973) and the 1973 Point Mugu earthquake (Ellsworth et al., 1973; Stierman and Ellsworth, 1976) as well as the local geology (Ziony and Yerkes, 1985).

Intensities. Isoseismal maps of the 1930 and 1979 main shocks are shown in Figure 8. The isoseismal map of the 1930 Santa Monica main shock was prepared by Gutenberg et al. (1932). They noted significant site effects (resulting in higher intensities than expected) at some locations in the Los Angeles basin and San Fernando Valley. They also reported unusually high intensities to the east, at Riverside intensity V, at San Jacinto intensity IV, and at Hemet intensity IV, which is located at an epicentral distance of $160 \mathrm{~km}$.

Stover et al. (1980) prepared the isoseismal map for the 1979 Malibu earthquake shown in Figure 8 . They reported $0.09 \mathrm{~g}$ acceleration (the highest recorded) at Topanga, at an epicentral distance of $20 \mathrm{~km}$. For comparison, Gutenberg et al. (1932) found the highest intensity of VIII was also reported at Topanga during the 1930 main shock. Stover et al. (1980) report intensities of VI along the Malibu coast and at several sites in the San Fernando Valley. They also showed anomalously high intensities extending to the east (Palm Springs) and the northeast (Barstow) (Figure 8).

A comparison of the isoseismal maps for the 1930 and the 1979 main shocks shows: (1) the 1930 main shock was, in general, felt over a larger area than the 1979 main shock; (2) the isoseismal area of intensity VI and larger is approximately 1300 $\mathrm{km}^{2}$ for the 1930 main shock and approximately $800 \mathrm{~km}^{2}$ for the 1979 main shock; and (3) in both cases, local site effects appear to result in locally anomalously high intensities.

Toppozada (1975) derived an empirical relationship between earthquake magnitude and the area enclosed by various isoseismal lines. His magnitude-intensity areas relationship for the isoseismal line VI predicts $742 \mathrm{~km}^{2}$ for $M_{L}=5.0$ and 1276 $\mathrm{km}^{2}$ for $M_{L}=5.2$, which agrees quite well with reported intensities in Figure 8.

The higher intensities reported for the 1930 main shock suggest that the event was both larger and located closer to the coast line than the 1979 earthquake. This observation supports the conclusion of this paper that the two main shocks were located on different faults.

\section{Faulting in North Santa Monica Bay}

To analyze the three-dimensional distribution of the 1979 hypocenters, the slip vector orientations were plotted using stereoscopic projection (Figure 9). Each slip vector is shown as a line centered within a circle that coincides with the plane of slip. The northerly dipping plane from each of the 21 focal mechanisms was selected for plotting. A view from above the epicentral zone shows the planes plunging beneath the Malibu coast. The perimeter of the northerly dipping plane of the main shock focal mechanism (which is assumed to be the rupture surface of the main shock) is lined with aftershocks, both within the assumed rupture surface as well as along smaller subparallel surfaces (Figure 9).

This almost volumetric distribution of aftershock hypocenters is similar to the aftershock distribution of the 1973 Point Mugu $\left(M_{L}=6.0\right)$ earthquake, (Stierman and Ellsworth, 1976). The aftershock distribution of the 1971 San Fernando earthquake also shows a similar volumetric distribution around the rupture surface of the main shock (Whitcomb et al., 1973). Hence, the spatial distribution of the aftershocks of the three moderate to large earthquakes that have occurred along 

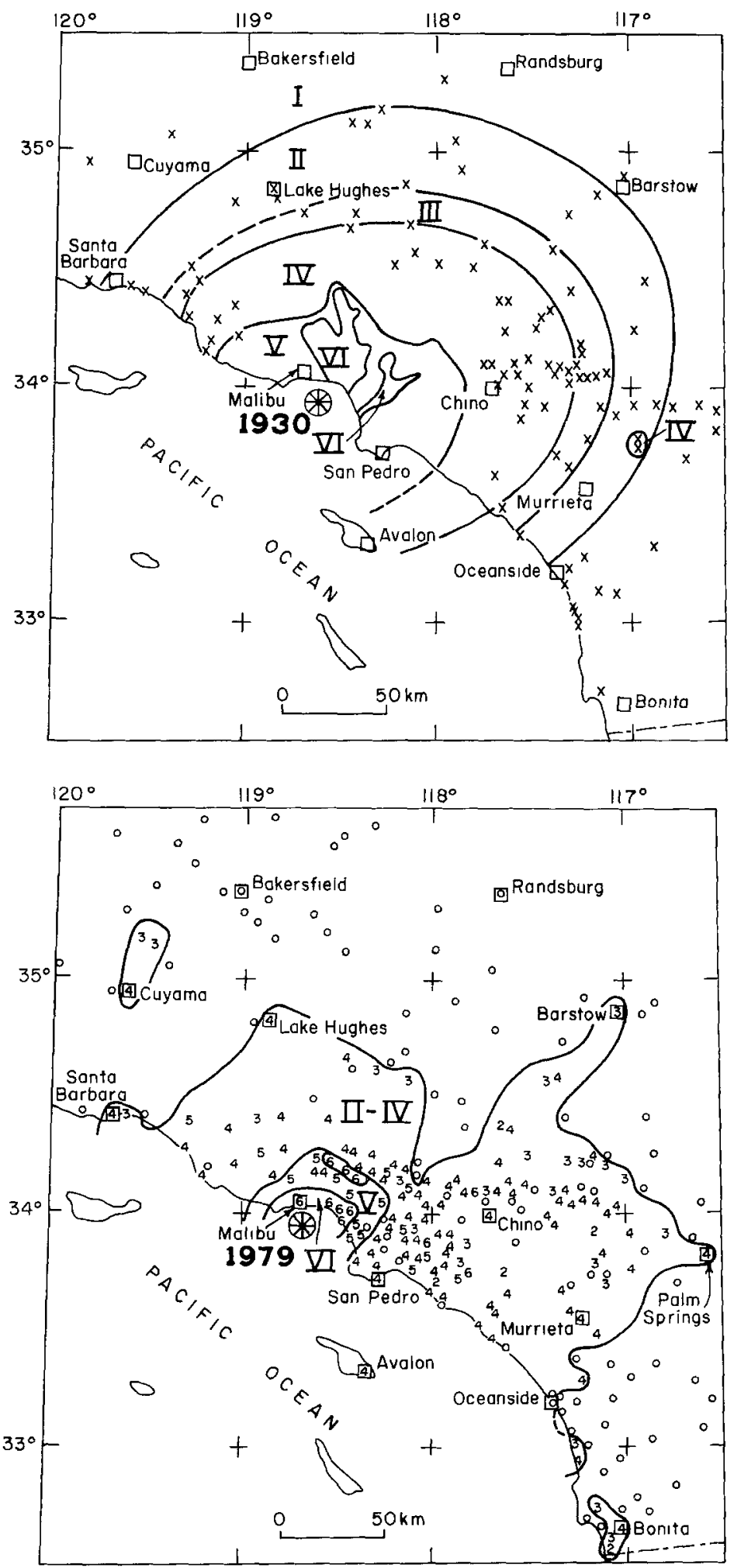

FIG. 8. Roman numerals show Modified Mercalli intensities between isoseismals. Star indicates location of respective main shock. (Top) Isoseismal map for the 1930 Santa Monica $\left(M_{L}=5.2\right)$ main shock prepared by Gutenberg et al. (1932). The X's indicate sites where the shock was felt. The VI isoseismal is reproduced from Figure 2 in Gutenberg et al. (1932). (Bottom) Isoseismal map for the 1979 Malibu $\left(M_{L}=5.0\right)$ main shock prepared by Stover et al. (1980). Numbers indicate intensity at that site. Note the difference in the area enclosed by the $\mathrm{V}$ isoseismal. 

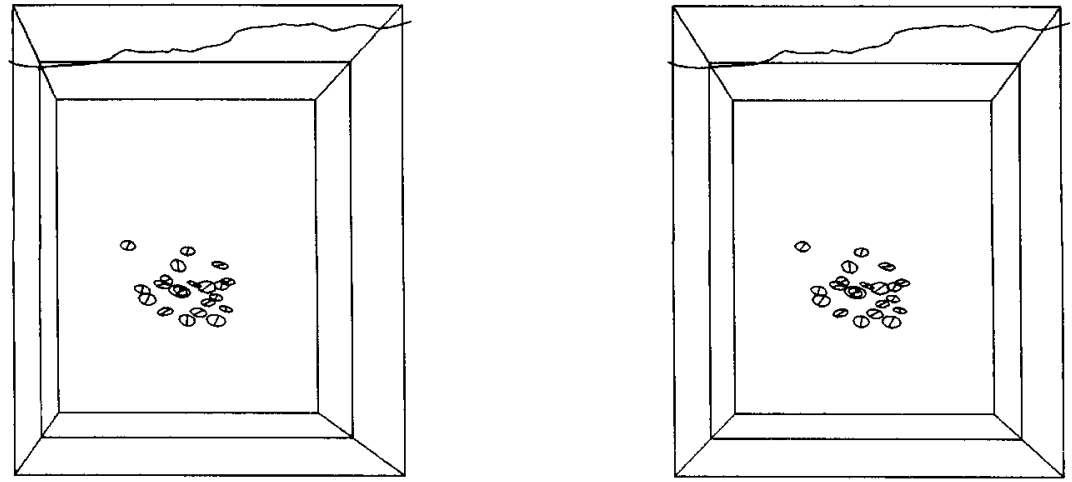

FIG. 9. A three-dimensional stereoscopic projection of the fault plane solutions of the main shock and 20 aftershocks in Figure 7. A focal mechanism is represented by a circle oriented in the plane of slip located at the hypocenter. The direction of slip is indicated by the diameter in each circle. The cube with $20 \mathrm{~km} \times 31 \mathrm{~km}$ sides is included for reference. The view is (from above) looking down toward the preselected north-dipping plane of the focal mechanisms. The size of the circles is proportional to magnitude, and the main shock is at the center of the projection. This figure was prepared using a computer program by German and Johnson (1982).

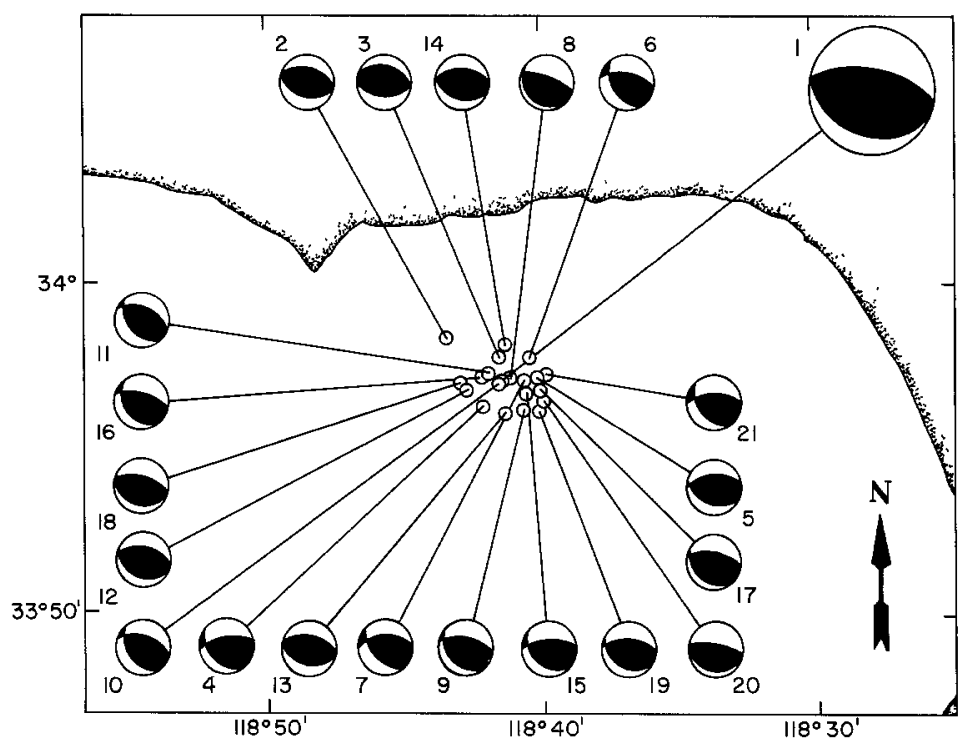

FIG. 10. Lower hemisphere focal mechanisms for the 1979 Malibu earthquake $(M=5.0)$ (large symbol to the upper right) and 20 aftershocks of magnitude greater than 3.0. Numbers shown adjacent to each mechanism refer to Table 4.

the southern frontal fault system of the Transverse Ranges are all characterized by a westerly or west-northwest trend with an almost volumetric distribution surrounding the fault plane of the main shock.

The lower hemisphere, single-event focal mechanisms that are shown in Figure 10 all show very similar solutions, predominantly reverse faulting on west-trending planes. The focal mechanism of the main shock is similar to the focal mechanism of the 1973 Point Mugu earthquake located $25 \mathrm{~km}$ to the west along the same fault system (Ellsworth et al., 1973; Stierman and Ellsworth, 1976). The north-dipping fault plane for the 1979 Malibu earthquake strikes $\mathrm{N} 100^{\circ} \mathrm{E}$ and dips $60^{\circ}$ to the north while the north-dipping fault plane of the 1973 Point Mugu earthquake 
strikes $\mathrm{N} 80^{\circ} \mathrm{E}$ and dips $36^{\circ}$ to the north (Stierman and Ellsworth, 1976). These two focal mechanisms therefore suggest uniform regional stress that causes reverse faulting with north-over-south slip. The similarity of the aftershock mechanisms of the 1979 Malibu earthquake is also illustrated by the $P$ and $T$ axes plot in Figure 11. The distribution of $P$ axes points in an average direction of $\mathrm{N} 15^{\circ}$ to $25^{\circ} \mathrm{E}$ and nearly horizontal while the $T$ axes are almost vertical. The $P$ axes distribution of the Point Mugu aftershocks is almost identical to the results of this study shown in Figure 11. Similarly, the 1978 Santa Barbara $\left(M_{L}=5.3\right)$ main shock and its aftershocks that were located at the southern edge of the western Transverse Ranges showed reverse mechanisms with horizontal $P$ axes pointing slightly east of north (Corbett and Johnson, 1982).

The interpretation of the tectonic deformation taking place in Santa Monica Bay is illustrated in a schematic cross-section (Figure 12). Since the $1979 \mathrm{Malibu}$ earthquake is consistent with a west-trending fault and north-over-south reverse slip, it probably occurred on the eastern end of the Anacapa-Dume fault. A proposed extension of the eastern end of the Anacapa-Dume fault is shown schematically as a thin dashed line in Figure 12 (top). The geologic mapping of faults in the bay sediments is based on subjective interpretation of shallow seismic profiling (e.g., Junger and Wagner, 1977). Since debris flows and gravity slides heading into the Santa Monica basin cross this area, the identification of the surface expression of the Anacapa-Dume fault may be difficult (see also, Clarke et al., 1985).

The relocated epicenter of the 1930 main shock is located near the western end of the Santa Monica fault. If the 1930 main shock is assumed to have similar reverse mechanisms as the 1979 main shock, then the 1979 and 1930 main shocks define an $8-$ to $10-\mathrm{km}$ north-south sidestep between the Anacapa-Dume and Santa Monica faults. This assumption of similar reverse mechanisms is not unreasonable, since both main shocks are located within the thrust faulting regime of the Tranverse Ranges. Such offsets are often considered to be regions of stress concentration where earthquake rupture may initiate or terminate (e.g., King and Nabelek, 1985).

The schematic cross-section in Figure 12 (bottom) shows a simplified model of the faulting process that causes north-south thrusting and associated crustal

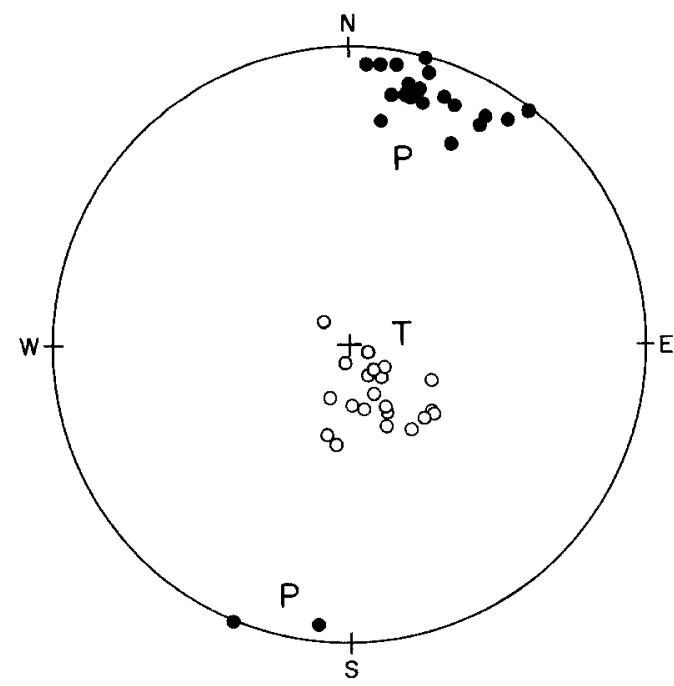

FiG. 11. Plot of $P$ and $T$ axes for the main shock-aftershock sequence. 

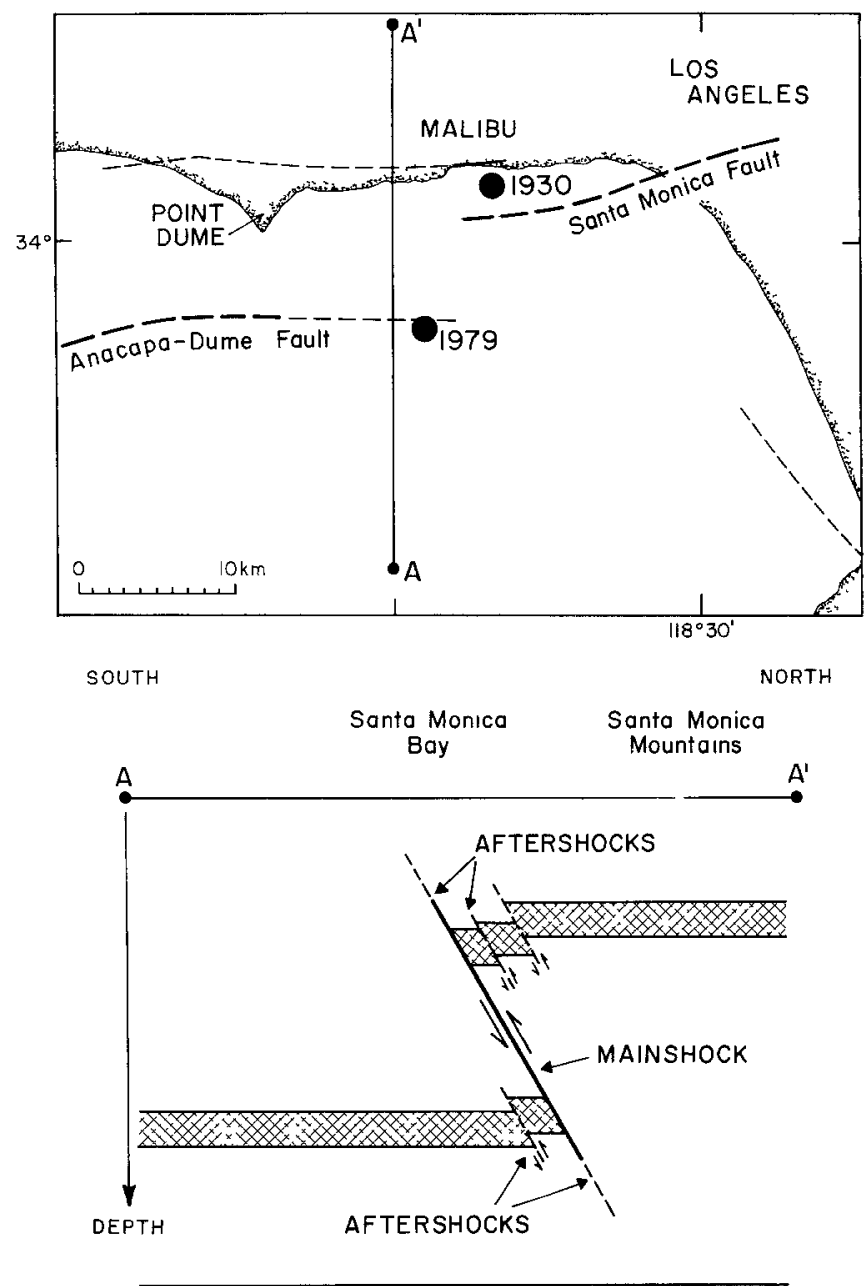

FiG. 12. (Top) The relocated 1979 and 1930 epicenters. A proposed extension of the Anacapa-Dume fault to the east is shown as a thin dashed line. (Bottom) A schematic north-south cross-section illustrating the type of faulting that occurred during the 1979 Malibu main shock-aftershock sequence.

shortening and uplift. The schematic cross-section also shows slip on the main fault plane of the main shock as well as slip on smaller faults that may have occurred during the extensive aftershock sequence. As discussed previously, this pattern of north over south reverse faulting on multiple subparallel planes has been documented in several other earthquake sequences in the Transverse Ranges.

\section{Discussion}

The 1971 San Fernando, 1973 Point Mugu, and 1979 Malibu earthquakes occurred near the southern margin of the Transverse Ranges. They can all be associated with fault planes that strike to the west or west-northwest and dip steeply to the north. It is noteworthy that none of these earthquakes are associated with shallowdipping thrust faults, often referred to as regional decollement (e.g., Hadley and Kanamori, 1978; Webb and Kanamori, 1985). The idea of subhorizontal detachment surface beneath the Transverse Ranges is mainly based on a handful of focal mechanisms of small deep earthquakes $(15$ to $25 \mathrm{~km}$ ) that are consistent with 
subhorizontal reverse faulting (e.g., Webb and Kanamori, 1985). Such a low-angle detachment fault is also proposed by several models of aseismic subduction of the lithosphere beneath the Transverse Ranges (Bird and Rosenstock, 1984; Humphreys, 1985). Therefore, it appears that if the detachment surface exists, the deformation along it may be mostly aseismic, and brittle-elastic deformation occurs only in the uppermost $15 \mathrm{~km}$ of the crust.

The vertical component of the geologic slip rates on the Santa Monica fault vary from 0.17 to $0.39 \mathrm{~mm} / \mathrm{yr}$ (Clark et al., 1984; Ziony and Yerkes, 1985). This can be compared to the horizontal component of slip rates along the northern branch of the Newport-Inglewood fault that ranges from 0.1 to $1.2 \mathrm{~mm} / \mathrm{yr}$ (Clark et al., 1984). The west-trending reverse faults along the southern margin of the Transverse Ranges thus present similar seismic hazards to the Los Angeles metropolitan area as the known strike-slip faults in the basin itself.

The segmentation of the Santa Monica fault with an 8- to $10-\mathrm{km}$ lateral sidestep with respect to the Anacapa-Dume fault, however, implies that these two faults are unlikely to rupture in one large earthquake. Further studies of small earthquakes occurring along the southern Transverse Ranges may aid in defining the lateral continuity and characteristic dimensions of fault segments that are likely to rupture in a damaging earthquake.

\section{CONCLUSIONS}

Relocation of the epicenters of the 1930 Santa Monica $\left(M_{L}=5.2\right)$ main shock and the 1979 Malibu $\left(M_{L}=5.0\right)$ main shock suggests that they occurred on the Santa Monica and Anacapa-Dume faults, respectively. The two main shocks are consistent with an 8- to 10-km north-south sidestep between the Anacapa-Dume and Santa Monica faults. Hence, these two fault systems are unlikely to rupture simultaneously in one large earthquake. The focal mechanisms of the $1979 \mathrm{Malibu}$ main shock and 20 of its aftershocks show almost pure reverse faulting on westtrending planes. The north-dipping nodal plane with north-over-south slip is interpreted to be the plane of faulting, since it is consistent with the mapped surface geology and the known faulting of other moderate-sized earthquakes along the southern margin of the Transverse Ranges.

\section{ACKNOWLEDGMENTS}

We are indebted to Lucile M. Jones for making copies of the CIT/USGS southern California network data available and for critical reviews. We also thank John K. McRaney for reviewing the manuscript. Copies of photographic records and phase cards of the 1930 and 1979 main shocks were provided by Paul Roberts of Caltech. This research was supported by USGS Grants 14-08-0001-G983 and -G1158 and USGS Contract 14-08-0001-21858. The figures were drafted by Janet Dodds and the manuscript typed by Sue Turnbow.

\section{REFERENCES}

Bird, P. and R. W. Rosenstock (1984). Kinematics of present crust and mantle flow in southern California, Geol. Soc. Am. Bull. 95, 946-957.

Clark, M. M., J. J. Lienkaemper, D. S. Harwood, K. R. Lajoie, J. C. Matti, J. A. Perkins, M. J. Rymer, A. M. Sarna-Wojcicki, R. V. Sharp, J. D. Sims, J. C. Tinsley, III, and J. I. Ziony (1984). Preliminary slip-rate table and map of late-Quaternary faults of California, U.S. Geol. Surv., Open-File Rept. 84106,5 sheets. scale $1: 1,000,000$.

Clarke, S. H., Jr., H. G. Greene, and M. P. Kennedy (1985). Identifying potentially active faults and unstable slopes offshore, in Evaluating Earthquake Hazards in the Los Angeles Region, J. I. Ziony, Editor, U.S. Geol. Surv. Profess. Paper 1360, 347-373.

Corbett, E. J. (1984). Seismicity and crustal structure studies of southern California, Tectonic implica- 
tions from improved earthquake locations, Ph.D. Thesis, California Institute of Technology, Pasadena, California, 231 pp.

Corbett, E. J. and C. E. Johnson (1982). The Santa Barbara, California, earthquake of 13 August 1978, Bull. Seism. Soc. Am. 72, 2201-2226.

Ellsworth, W. L., R. H. Campbell, D. P. Hill, R. A. Page, R. W. Alewine, T. C. Hanks, T. H. Heaton, J. A. Hileman, H. Kanamori, B. Minster, and J. H. Whitcomb (1973). Point Mugu, California, earthquake of 21 February 1973 and its aftershocks, Science 182, 1127-1129.

German, P. and C. Johnson (1982). STEREO: a computer program for projecting and plotting stereograms, U.S. Geol Surv., Open-File Rept. 82-726.

Given, D. D. and C. L. Koesterer (1983). Station arrival data for a quarry blast on Santa Catalina Island, California, U.S. Geol. Surv., Open-File Rept. 83-462, 12 pp.

Gutenberg, B., C. F. Richter, and H. O. Wood (1932). The earthquake in Santa Monica Bay, California, on August 30, 1930, Bull. Seism. Soc. Am. 22, 138-154.

Hadley, D. and H. Kanamori (1978). Recent seismicity in the San Fernando region and tectonics in the west-central Transverse Ranges, California, Bull. Seism. Soc. Am. 68, 1449-1457.

Humphreys, E. D. (1985). Studies of the crust-mantle system beneath southern California, Ph.D. Dissertation, California Institute of Technology, Pasadena, California, 189 pp.

Junger, A. and H. C. Wagner (1979). Geology of the Santa Monica and San Pedro basins, California Continental Borderland, U.S. Geol. Surv. Miscellaneous Field Studies Map MF-820, 5 sheets, 1 pamphlet, scale $1: 250,000$.

King, G. and J. Nabelek (1985). Role of fault bends in the initiation and termination of earthquake rupture, Science 228, 984-987.

Klein, F. W. (1985). User's guide to HYPOINVERSE, a program for VAX and PC350 computers to solve for earthquake locations, U.S. Geol. Surv., Open-File Rept. 85-515, 53 pp.

Norris, R., C. E. Johnson, L. M. Jones, and L. K. Hutton (1986). The bulletin of the southern California seismic network, U.S. Geol. Surv., Open-File Rept. 86-96, 32 pp.

Reasenberg, P. and D. Oppenheimer (1985). FPFIT, FPPLOT and FPPAGE: Fortran computer programs for calculating and displaying earthquake fault-plane solutions, U.S. Geol. Surv., Open-File Rept. 85-739, 46 pp.

Stierman, D. J. and W. Ellsworth (1976). Aftershocks of the February 21, 1973 Pt. Mugu, California earthquake, Bull. Seism. Soc. Am. 66, 1931-1952.

Stover, C. W., J. H. Minsch, B. G. Reagor, and P. K. Smith (1980). Earthquakes in the United States, January-March, 1979, U.S. Geol. Surv. Circular 836-A, A24-A26.

Toppozada, T. R. (1975). Earthquake magnitude as a function of intensity data in California and western Nevada, Bull. Seism. Soc. Am. 65, 1223-1238.

Toppozada, T. R., D. L. Parke, and C. T. Higgins (1978). Seismicity of California 1900-1931, Special Report 135, Callfornia Division of Mines and Geology, Sacramento, California, 39 pp.

Webb, T. H. and H. Kanamori (1985). Earthquake focal mechanisms in the eastern Transverse Ranges and San Emigdio mountains, southern California and evidence for a regional decollement, Bull. Seism. Soc. Am. 75, 737-757.

Whitcomb, J. H., C. R. Allen, J. D. Garmany, and J. A. Hileman (1973). San Fernando earthquake series, 1971: focal mechanisms and tectonics, Rev. Geophys. Space Phys. 11, 693-730.

Ziony, J. I. and R. F. Yerkes (1985). Evaluating earthquake and surface-faulting potential, in Evaluating Earthquake Hazards in the Los Angeles Region, J. I. Ziony, Editor, U.S. Geol. Surv. Profess. Paper $1360,43-91$.

Ziony, J. I., C. M. Wentworth, J. M. Buchanan-Banks, and H. C. Wagner (1974). Preliminary map showing recency of faulting in coastal southern California, U.S. Geol. Surv., Map MF-585, 3 sheets, 1 pamphlet, scale 1:250,000.

\section{DEPARTMENT OF GEOlOGiCAL SCIENCES \\ UNIVERSITY OF SOUTHERN CALIFORNIA \\ LOS ANGELES, CALIFORNIA 90089-0741}

Manuscript received 14 April 1986 